\title{
Lemierre syndrome: more than just a sore throat
}

\author{
Christine Azzopardi, Reuben Grech, Adrian Mizzi
}

Department of Radiology, Mater Dei Hospital, Msida, Malta

\section{Correspondence to} Dr Christine Azzopardi, chrissyazz@yahoo.com
CrossMark

To cite: Azzopardi $C$, Grech R, Mizzi A. BMJ Case Rep Published online: [please include Day Month Year] doi:10.1136/bcr-2013201868

\section{DESCRIPTION}

A previously healthy, 35-year-old, immunocompetent man presented with a 2-day history of sore throat and unilateral swelling of the right neck. The patient was found to be tachycardic and pyrexic on clinical examination.

Lemierre syndrome is the sequela of acute pharyngotonsillitis. The cause is often the anaerobe Fusobacterium necrophorum. ${ }^{1}$ Patients present with septicaemia and a preceding history of upper respiratory tract infection. The infection primarily affects the palatine tonsils, spreading along the fascial planes into the carotid space resulting in thrombophlebitis of the internal jugular vein. ${ }^{1}$

The discovery of a thrombosed internal jugular vein on imaging is crucial in making the diagnosis. The first-line imaging of choice is ultrasound. This demonstrates the expansion of the internal jugular vein by thrombus, together with incompressibility and absent Doppler flow (figure 1). Precontrast and postcontrast CTs of the neck would confirm a central filling defect in keeping with thrombus formation, with fat stranding in the adjacent carotid space. ${ }^{2}$ MRIs reveal enhancement of the venous wall and surrounding fat within the ipsilateral carotid sheath (figure 2).

The diagnosis is a combination of these radiological findings together with a history of recent pharyngotonsillitis and culture of an anaerobic bacterium.

Aggressive antimicrobial therapy together with anticoagulation is the treatment of choice. ${ }^{3}$ Untreated, septic emboli may develop with consequent infarcts or abscesses. This usually affects the lungs and joints, however, any organ can be affected. This condition should be kept in mind when dealing with complicated upper respiratory tract infections.

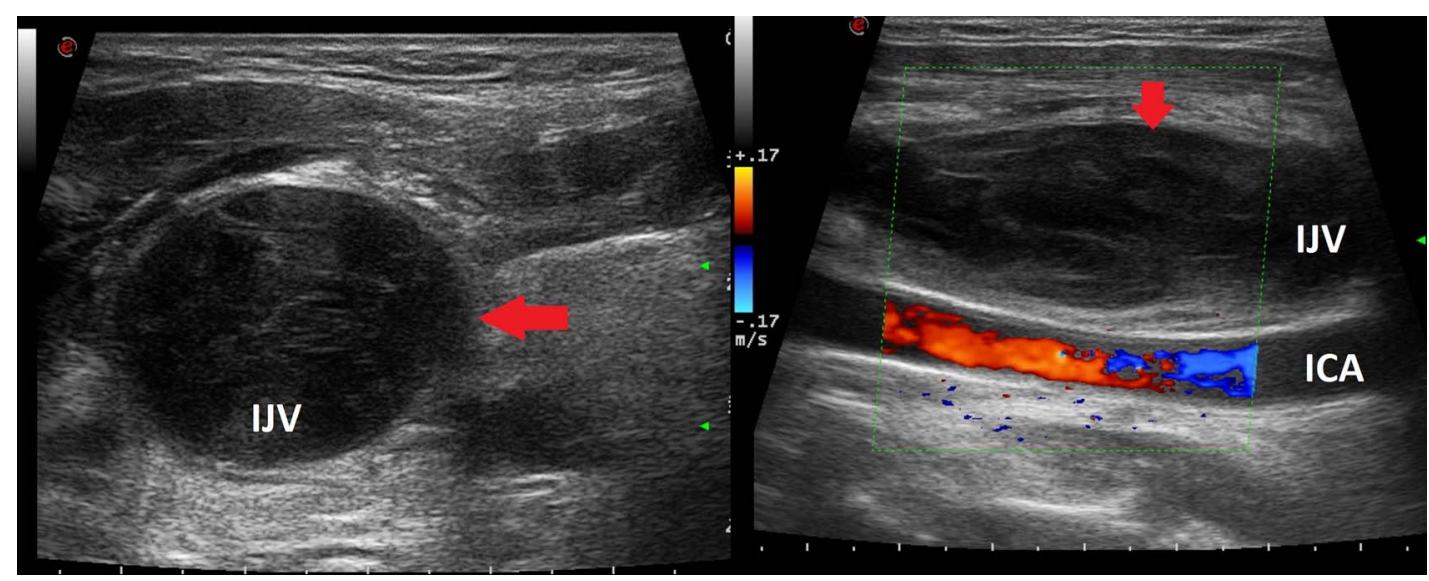

Figure 1 Ultrasound images on the left: axial image of B-mode ultrasound of the right internal jugular vein (labeled (IJV) (red arrow). This is distended, in keeping with thrombus formation. On the right: longitudinal image of colour Doppler ultrasound demonstrating absence of flow in the right IJV indicative of occlusion. The right internal carotid

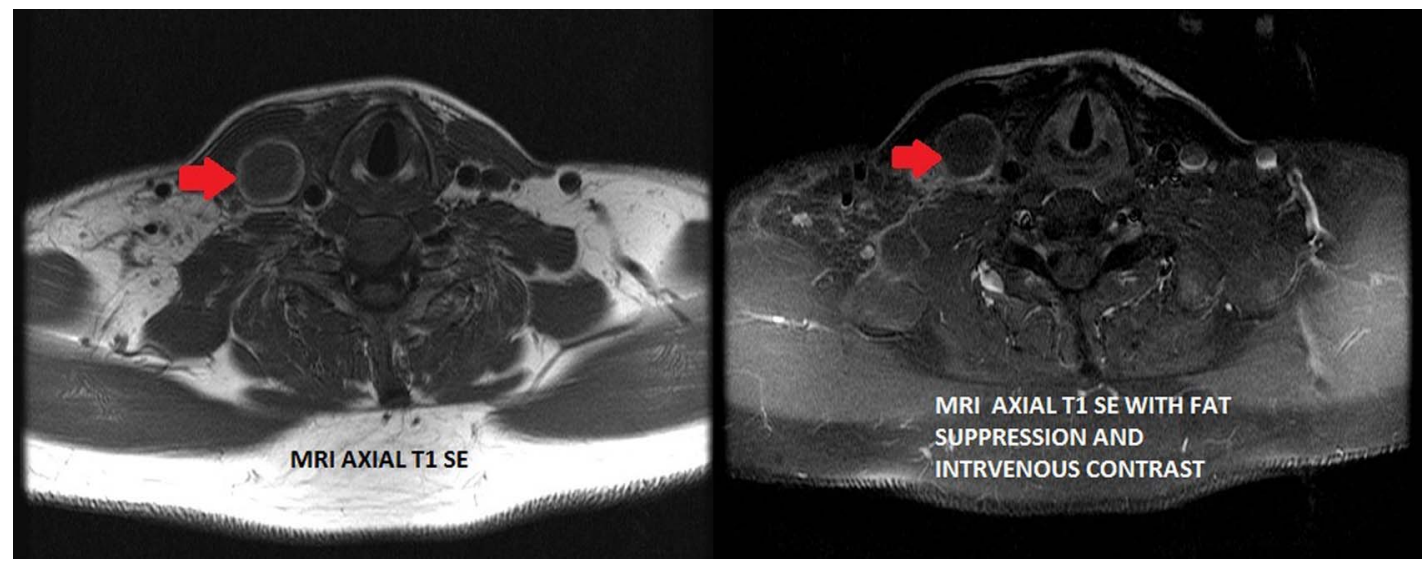

Figure 2 MRI on the left: axial T1 SE image showing the expanded and thrombosed right internal jugular vein (red arrow). On the right: axial T1 SE with fat suppression and intravenous contrast note the thrombosed right internal jugular vein (red arrow). There is contrast enhancement of the venous wall and the surrounding fat. 


\section{Learning points}

- Early recognition of the condition is vital to prevent serious complications.

- Radiological investigation is paramount in confirming the diagnosis.

- The key finding is internal jugular vein thrombophlebitis.

Contributors CA performed the literature review and drafted the write up of the article. RG and AM made the radiological diagnosis of the case and reported the imaging findings.
Competing interests None.

Patient consent Obtained.

Provenance and peer review Not commissioned; externally peer reviewed.

\section{REFERENCES}

1 Ridgway JM, Parikh DA, Wright $\mathrm{R}$, et al. Lemierre syndrome: a pediatric case series and review of literature. Am J Otolaryngol 2010;31:38-45.

2 Screaton JN, Ravenel JG, Lehner PJ, et al. Lemierre syndrome: forgotten but not extinct-report of four cases. Radiology 1999;213:369-74.

3 Riordan T, Wilson M. Review: Lemierre's syndrome: more than a historical curiosa. Postgrad Med J 2004;80:328-34.

Copyright 2013 BMJ Publishing Group. All rights reserved. For permission to reuse any of this content visit http://group.bmj.com/group/rights-licensing/permissions.

BMJ Case Report Fellows may re-use this article for personal use and teaching without any further permission.

Become a Fellow of BMJ Case Reports today and you can:

- Submit as many cases as you like

- Enjoy fast sympathetic peer review and rapid publication of accepted articles

- Access all the published articles

- Re-use any of the published material for personal use and teaching without further permission

For information on Institutional Fellowships contact consortiasales@bmjgroup.com

Visit casereports.bmj.com for more articles like this and to become a Fellow 